\title{
SISTEM TANDA DALAM KUMPULAN PUISI MENGUNJUNGI HUJAN YANG BERTEDUH DI MATAMU KARYA ALFIN RIZAL
}

\author{
Ainul Inayah ${ }^{1)}$ \\ Irma Arifah 1) \\ 1) STKIP PGRI Trenggalek \\ ainulinayah07@gmail.com zonalinguafranca@gmail.com
}

\begin{abstract}
ABSTRAK: Tujuan umum dari penelitian ini yaitu untuk mendapatkan gambaran objektif tentang sistem tanda dalam puisi Mengunjungi Hujan yang Berteduh di Matamu karya Alfin Rizal. Dalam penelitian ini peneliti merumuskan masalah sebagai berikut. (1) Bagaimanakah gambaran ikon dalam kumpulan puisi "Mengunjungi Hujan yang Berteduh di Matamu" karya Alfin Rizal? (2) Bagaimana gambaran indeks yang terdapat kumpulan puisi "Mengunjungi Hujan yang Berteduh di Matamu" karya Alfin Rizal? (3)Bagaimana gambaran simbol yang terdapat dalam kumpulan puisi "Mengunjungi Hujan yang Berteduh di Matamu" karya Alfin Rizal?. Penelitian ini menggunakan metode dokumentasi. Hasil analisis data, paparan data, dan temuan data menunjukkan bahwa, (1) terdapat gambaran ikon dalam kumpulan puisi "Mengunjungi Hujan yang Berteduh di Matamu" karya Alfin Rizal berupa tanda yang memiliki kemiripan dengan apa yang dilihat oleh pemakainya, (2) terdapat gambaran indeks dalam kumpulan puisi "Mengunjungi Hujan yang Berteduh di Matamu" karya Alfin Rizal berupa tanda yang memiliki hubungan sebab akibat antara tanda dan petanda, (3) terdapat gambaran simbol dalam kumpulan puisi "Mengunjungi Hujan yang Berteduh di Matamu" karya Alfin Rizal berupa tanda yang dapat mewakili sesuatu dan tidak mengikuti suatu aturan.
\end{abstract}

Kata kunci : Puisi, Ikon, Indeks, Simbol.

ABSTRACT: The general objective of this research is to obtain an objective picture of the sign system in the poem "Mengunjungi Hujan Berteduh di Matamu" by Alfin Rizal. In this study, the researcher formulated the following problems. (1) How is the image of the icon in the collection of poetry "Mengunjungi Hujan yang Berteduh di Matamu" by Alfin Rizal? (2) What is the description of the index contained in the collection of poetry "Mengunjungi Hujan yang Berteduh di Matamu" by Alfin Rizal? (3) What is the description of the symbols contained in the collection of poetry "Mengunjungi Hujan yang Berteduh di Matamu" by Alfin Rizal? This research uses documentation method. The results of data analysis, data exposure, and data findings show that, (1) there is an iconic image in the collection of the poem "Mengunjungi Hujan yang Berteduh di Matamu " by Alfin Rizal in the form of a sign that is similar to what the wearer sees, (2) there is a description index in the collection of poems "Mengunjungi Hujan yang Berteduh di Matamu" by Alfin Rizal is a sign that has a causal relationship between signs and signs, (3) there is a symbolic image in the collection of poetry "Mengunjungi Hujan yang Berteduh di Matamu " by Alfin Rizal in the form of signs that can represent something and not follow a rule

Keywords: Poetry, Icons, Indexes, Symbols.

\section{PENDAHULUAN}

Karya sastra merupakan karya yang imajinatif, dibagi menjadi tiga yaitu prosa, drama, dan puisi. Puisi merupakan karya sastra yang memiliki makna yang indah, dalam penyampaiannya melalui bahasa dan rangkaian kata yang disusun dengan indah. Dalam mengkaji karya sastra terdapat beberapa pendekatan yang tepat digunakan untuk mengungkap maksud yang tersirat dalam ide, gagasan, dan pikiran pengarang. Salah satu pendekatan tersebut, yaitu semiotik yang mengkhususkan pada sistem tanda. Scholes 
(dalam Kris Budiman, 2011:3) mengungkapkan bahwa sistem tanda merupakan sebuah pembelajaran tentang kode, yaitu sistem yang menjelaskan tentang sebuah wujud tertentu yang memiliki tanda yang bermakna. Suatu kajian tentang tanda merupakan kajian bahasa karena bahasa merupakan suatu media dalam mengartikan bahkan menyampaikan sebuah makna yang memiliki aspek sesuai dengan situasi yang tepat dan informatif. Misalnya dalam sebuah puisi tidak dipahami sebagai bentuk dari morfem tanpa melihat satuan dan pola untuk mengartikan sejumlah makna dan tujuan dalam pnyampaian puisi.

Pendekatan yang digunakan dalam penelitian merupakan upaya untuk mengungkapkan tanda yang terkandung di dalam puisi. Memaknai sebuah puisi berarti mencari tanda-tanda yang terdapat di dalamnya. Menurut Marcel Danesi (2010:47) tedapat beberapa tiga pembagian tanda yaitu, icon, indek, dan simbol. Dari latar belakang masalah yang diungkapkan peneliti, maka peneliti melakukan penelitian yang berjudul "Sistem Tanda dalam Kumpulan Puisi "Mengunjungi Hujan yang Berteduh di Matamu" karya Alfin Rizal”. Penulis meneliti kumpulan puisi Mengunjungi Hujan yang Berteduh di Matamu karya Alfin Rizal karena penulis meneliti dan melihat bahwa terdapat beberapa tanda yang ada dalam kumpulan puisi tersebut. Setelah itu penulis memiliki rasa ingin tahu tentang tanda apa saja yang terkandung dalam kumpulan puisi tersebut dan apa makna dari tanda yang ada dalam kumpulan puisi Mengunjungi Hujan yang Berteduh di Matamu karya Alfin Rizal. Selain itu, kumpulan pusi tersebut menggunakan bahasa kiasan yang sarat akan makna, sedikit misterius, namun tetap memiliki daya tarik yang luar biasa. Setelah itu penulis mencari kajian yang tepat untuk menganalisis kumpulan puisi tersebut yaitu menggunakan kajian semiotik yang mempelajari tentang sebuah tanda. Tanda merupakan sesuatu yang tidak dapat dipisahkan dalam kehidupan manusia karena sebuah tanda memiliki makna dan arti untuk berkomunikasi manusia.

Dalam penelitian ini penulis akan menganalisis sistem tanda dalam kumpulan puisi Mengunjungi Hujan yang Berteduh di Matamu karya Alfin Rizal dengan ikon, indeks, dan simbol sebagai spesifikasi pendekatannya. Dalam penelitian ini peneliti merumuskan masalah sebagai berikut. (1) Bagaimanakah gambaran ikon dalam kumpulan puisi "Mengunjungi Hujan yang Berteduh di Matamu" karya Alfin Rizal? (2) Bagaimana gambaran indeks yang terdapat dalam kumpulan puisi "Mengunjungi Hujan yang Berteduh di Matamu" karya Alfin Rizal? (3)Bagaimana gambaran simbol yang terdapat dalam kumpulan puisi "Mengunjungi Hujan yang Berteduh di Matamu" karya Alfin Rizal?. Tujuan dalam penelitian ini yaitu untuk mendapatkan gambaran tentang sistem tanda dalam puisi "Mengunjungi Hujan yang Berteduh di Matamu" karya Alfin Rizal. Penetian ini dapat digunakan sebagai bahan rujukan dan pengembangan peneliti lain yang akan mengembangkan penelian ini, dapat digunakan mahasiswa untuk memahami ide atau gagasan baru yang lebih kreatif di masa yang akan datang demi kemajuan mahasiswa. 


\section{METODE PENELITIAN}

Jenis penelitian ini adalah penelitian kualitatif dan bersifat deskriptif, karena hasil penelitian dikumpulkan dalam bentuk kata. Sejalan dengan hal tersebut, Moleong (2017:11) mengungkapkan bahwa dalam penelitian kualitatif data yang dikumpulkan yaitu hanya data yang berupa kata-kata. Prosedur penelitian dalam penelitian kualitatif mencakup tiga hal yaitu, (1) Tahap persiapan, pada tahap ini ada beberapa langkah dalam melaksanakan penelitian, antara lain: (a) memilih masalah, (b) melakukan studi pendahuluan, (c) merumuskan masalah, (d) memilih pendekatan, (e) memilih sumber data, (f) menentukan instrument penguumpulan data, (g) menyusun rencana penelitian. (2) tahap pelaksanaan, pada tahap ini ada beberapa langkah dalam melaksanakan penelitian, antara lain: (a) mencari data dan menghimpun sumber data utama dan data tambahan, (b) menganalisis data, (c) menarik kesimpulan. (3) tahap pelaporan, pada tahapan ini ada beberapa langkah dalam melaksanakan penelitian, antara lain: (a) menyusun laporan hasil penelitian, (b) mereview dan merevisi hasil laporan penelitian, (c) menggandakan hasil laporan penelitian. Metode yang digunakan dalam penelitian ini adalah dokumentasi. Tahapan yang dilakukan peneliti dalam mengumpulkan data penelitian ini meliputi (1) Membaca kumpulan puisi "Mengunjungi Hujan yang Berteduh di Matamu" karya Alfin Rizal secara cermat dan berulang-ulang, (2) Menandai kalimatkalimat atau kata- kata yang ada kaitannya dengan ikon, indeks, maupun simbol dalam puisi tersebut, (3) Mencatat kalimat-kalimat atau kata-kata yang ada kaitannya sama ikon, indeks, maupun simbol dalam puisi tersebut, (4) Menentukan dan mengklasifikasikan data ke dalam tabel korpus data atau alat pencatat data untuk dipastikan adanya icon, indek, maupun simbol. Dalam penelitian ini merupakan analisis tekstual dan sudah dimulai sejak proses pengumpulan data. Dalam penerapannya, metode ini berusaha menganalisis secara induktif. Dari semua data yang ada diperoleh kemudian diintepretasi, dikelompokkan, kemudian dideskripsikan sebagai hasil penelitian dengan melakukan tahapan-tahapan analisis data dari awal secara berulang-ulang. Aktivitas dalam menganalisis data menurut Miles dan Huberman dalam Sugiyono (2017:246) yaitu mereduksi data, menyajikan data, dan menarik kesimpulan.

\section{HASIL DAN PEMBAHASAN}

\section{Gambaran Ikon dalam Puisi "Mengunjungi Hujan yang Berteduh di Matamu" karya Alfin Rizal.}

Ikon merupakan tanda yang memiliki kesamaan atau kemiripan dengan apa yang dilihat oleh pemakainya. Di dalam ikon hubungan antara tanda dan objeknya terwujud sebagai "kesamaan dalam beberapa kualitas". Tanda sebagai ikon memiliki arti yang sederhana untuk mengkomunikasikan A maka diwakili oleh gambar A. Lukisan potret wajah yang menyerupai sesorang adalah ikon dari orang itu. (Kris Budiman , 2011:19). Salah satu contoh ada dalam puisi yang berjudul di gedung teater tua. 


\section{di gedung teater tua}

di gedung teater tua ini

ada pertunjukan hujan yang kurindukan

dan kursi-kursi penuh diisi basah sepi,

sepi yang kehilangan sapa; berwarna sepia

di gedung teater tua ini

dulu hujan jatuh seperti daun musim gugur

hatiku juga jatuh, mendarat di lirik matamu

mata yang menyanyikan lagu-tanpa-lirik

\section{(GIK/31)}

Pada puisi di gedung teater tua (GIK/31), kata 'kurindukan' merupakan ungkapan perasaan penyair yang menginginkan bertemu dengan seseorang yang dikasihinya. Kata 'kurindukan' merupakan tanda yang bersifat ikonik karena menyerupai dengan yang diwakili penyair pada puisi di atas. Kata 'hujan' menggambarkan air yang berjatuhan dari udara atau langit. Kata 'hujan' memiliki kesamaan dengan apa yang diwakili dalam puisi, yaitu hujan yang melukiskan tentang suatu kejadian atau peristiwa yang tidak dikehendaki oleh penulis yaitu, sebuah kesusahan. 'hujan' merupakan gambaran ikon karena memiliki kesamaan terhadap apa yang ada pada puisi. Kata 'musim gugur' merupakan sebuah musim peralihan dari musim panas ke musim dingin. Kata 'musim gugur' memiliki kesamaan dengan yang diwakilinya, seperti 'musim gugur' yang menggambarkan tentang sesuatu yang berguguran yaitu impian atau keinginan yang terhapuskan atau keinginan yang tidak akan pernah tercapai. Hal tersebut adalah tanda yang bersifat ikonik karena menyerupai apa yang direpresentasikan sama penyair dalam puisi tersebut.

\section{Gambaran Indeks dalam Puisi "Mengunjungi Hujan yang Berteduh di Matamu" karya Alfin Rizal.}

Menurut Alex Sobur, (2017:41) indeks adalah tanda memiliki hubungan sebab akibat. Salah satu contoh ada dalam puisi yang berjudul terasa teras ini.

\section{terasa teras ini}

\section{Setelah musim hujan, masih}

\section{terasa dingin teras rumah ini}

acapkali lidah kelu mengucap rindu

pada jelita kau yang terbenam gulita

dan merajuk kau yang kelewat manja

setelah musim hujan

lembab sekali teras ini terasa

jika kecuali mengenang kau 
kepalang jenuh aku, pada segala

yang kukenang,

sementara kau tak kuncung datang;

menemui bagian diri kita

yang hilang

\section{(GIN/45)}

Pada puisi terasa teras ini (GIN/45) terdapat indeks pada kutipan 'Setelah musim hujan' (sebab), 'masih terasa dingin teras rumah ini' (akibat). Pada kutipan 'setelah musim hujan' merupakan sebab yang terjadi sebagai bentuk ungkapan sebuah kesedihan yang dialami penulis dan sudah terjadi atau berlalu. 'masih terasa dingin teras rumah ini' menggambarkan akibat perasaan yang susah dilupakan dan masih membekas dalam hati. 'setelah musim hujan' (sebab), 'lembab sekali teras ini terasa' (akibat). Pada kutipan 'setelah musim hujan' merupakan sebab yang terjadi sebagai bentuk ungkapan sebuah kesedihan yang dialami penlis dan sudah terjadi atau berlalu. 'lembab sekali teras ini terasa' menggambarkan akibat kesedihan yang dialaminya, mata tak kunjung kering merasakan kejadian atau kesedihan tersebut. Hal tersebut menunjukkan adanya hubungan sebab akibat dengan apa yang diwakilinya.

Pengertian indeks juga diungkapkan oleh Marcel Danesi (2010:48) yaitu ikon sebagai pengganti atau penunjuk sesuatu yang ada hubungannya dengan sesuatu yang lain. Indeks sekedar mengidentifikan dimana seseorang berada. Bentuk yang identik dari indeks yaitu gerakan menunjuk atau mengarahkan jari telunjuk yang secara umum dugunakan manusia untuk menunjuk sesuatu. Banyak kata juga yang merupakan bentuk yang terkadung dari indeks: misalnya di sini, di sana, di atas, di bawah untuk menunjuk tempat tertentu pada saat sesorang mengucapkannya. Indeks juga merupakan ciri pembentukan identitas. Salah satu contoh ada dalam puisi yang berjudul Runcing Hujan

\section{runcing hujan}

di sanalah

nyawa kita bersenyawa

mendengar dengkur tekukur

ketika runcing hujan kalah

merancang tangga nada

memeluk basah tanah

saat tetumbuhan bersiut mesra

menggelitiki desir di dada

yang mati-matian kita jaga

(GIN/37) 
Pada puisi Runcing Hujan (GIN/27) terdapat kalimat di sanalah nyawa kita bersenyawa menggambarkan bahwa kisah cinta yang dialami oleh si penulis. Dimana mereka hidup bersama baik susah maupun senang akan mereka jalani bersama. Kalimat tersebut merupakan kegiatan menunjuk dan memastikan kadudukan sebuah peristiwa. Kegiatan menunjuk merupakan mengarahkan jari telunjuk yang secara umum digunakan semua orang untuk menunjukkan kedudukan atau tempat bahkan peristiwa seperti yang dimaksud pada kalimat 'di sanalah nyawa kita bersenyawa'.

\section{Simbol dalam Puisi "Mengunjungi Hujan yang Berteduh di Matamu" Karya Alfin Rizal.}

Simbol adalah tanda yang dapat mewakili sesuatu dan tidak mengikuti aturan tertentu. (Marcel Danesi, 2010:48). Salah satu contoh ada dalam puisi yang berjudul pada dada hujan.

\section{pada dada hujan}

pada dada hujan, ada lubang lapang

tempat semayam doa dan rindu

yang memohon, meronta

di ranting-ranting pohon

pada dada hujan, ada cemas menyaksikan gemas

luka runtuh dari tubuh langit, menyusuri bukit-

bukit sakit, menjerit seperti sauh berkelit dari

parit-parit. sementara bulan sore benam,

tenggelam dalam malam kelam.

pada dada hujan, ada kita mengandung mendung, meghitung satu dua tiga iba yang tiba di atas

tanah kuburan, hingga tak terhingga hitungan kita, juga hitungan kata, mengungkap rahasia cinta kita.

"pada dada hujan ini..." katamu.

"kita selalu gamang pada reda rintik

dan geming pada terik."

\section{(GSI/38)}

Puisi pada dada hujan (GSI/38), kalimat 'dada hujan' pada puisi tersebut menggambarkan tentang sebuah hati yang dimaksud sebagai ungkapan bahwa hati merupakan tempat untuk menyimpan segala keluh kesah, doa, dan sebagainya. Kalimat 'menjerit' menggambarkan tentang keluh kesah dan menangis karena sedih. Kalimat 'bulan sore benam' menandai tentang keindahan atau kebahagiaan yang hilang. 'malam kelam' menandai tentang malam yang dibalut dengan kesedihan. 'mendung' 
menyimbolkan sebuah kesedihan. Hal tersebut merupakan tanda yang dapat mewakili sesuatu dan tidak mengikuti aturan tertentu.

\section{KESIMPULAN}

Dalam penelitian ini dapat disimpulkan bahwa ikon memiliki kemiripan dengan apa yang dilihat oleh pemakainya dengan mengungkapkan B maka dapat diwakili oleh gambar B. Sedangkan indeks menunjukkan adanya hubungan sebab-akibat. Sepeti awan kelabu adalah tanda akan datangnya hujan. Serta simbol mewakili atau menjelaskan tentang sebuah bentuk atau dapat digunakan untuk menandai sebuah obyek. Seperti bentuk love melambangkan sebuah cinta dan kasih sayang. Hasil penelitian ini dapat dipakai sebagai salah satu referensi untuk mengembangkan penelitian lanjut mengenai sistem tanda dalam kumpulan puisi baik gambaran ikon, indeks, dan simbol.

\section{DAFTAR RUJUKAN}

Kris, Budiman. 2011. Semiotika Visual (Konsep, Isu, dan Problem Ikonitas). Yogyakarta: Jalasutra

Marcel, Danesi. 2010. Pengantar Memahami Semiotika Media. Yogyakarta: Jalasutra

Lexy J, Moleong. 2017. Metodologi Penelitian Kualitatif. Bandung: PT Remaja Rosdakarya

Alex, Sobur. 2017. Semiotika Komunikasi. Bandung: PT Remaja Rosdakarya

Alfin, Rizal. 2019. Mengunjungi Hujan yang Berteduh di Matamu. Yogyakarta: Rotasi Books

Sugiyono, 2017. Metode Penelitian Kuantitatif, Kualitatif, dan R\&D. Bandung: Alfabeta 
Volume 4, Nomor 2, Agustus 2020 